\title{
Analytical study on hexavalent chromium accumulation in plant parts of Pongamia pinnata (L.) Pierre and remediation of contaminated soil
}

\author{
Pratyush Kumar Das ${ }^{1}$ (D), Bidyut Prava Das ${ }^{2}$ (D), Patitapaban Dash ${ }^{1 *}$ \\ ${ }^{1}$ Centre for Biotechnology, Siksha 'O' Anusandhan (Deemed to be University), Bhubaneswar, India. \\ ${ }^{2}$ Department of Botany, Rama Devi Women's University, Bhubaneswar, India.
}

\section{ARTICLE INFO \\ Article history: \\ Received on: May 10, 2021 \\ Accepted on: July 29, 2021 \\ Available online: January 07, 2022}

\section{Key words:}

Heavy metal, hexavalent chromium, industrial, toxic, remediation, rhizospheric soil

\begin{abstract}
Hexavalent chromium $[\mathrm{Cr}(\mathrm{VI})]$ is a toxic oxidation state of the heavy metal $\mathrm{Cr}$, which has a wide range of industrial applications. Cr-based mining and industrial activities release $\mathrm{Cr}(\mathrm{VI})$ as a pollutant into the soil, which is responsible for pollution. Restoration of soil quality in these mining and industrial areas is highly essential for sustainable development and healthy living. The application of plant systems as a sink for the remediation of soil rich in $\mathrm{Cr}(\mathrm{VI})$ is a cost-effective technique to control soil pollution. The present study targets Pongamia pinnata (L.) Pierre as a biological sink for the remediation of $\mathrm{Cr}(\mathrm{VI})$-contaminated soil. The analytical study on Cr(VI) accumulation in plant parts of P. pinnata (L.) Pierre and the status of $\mathrm{Cr}(\mathrm{VI})$ present in its rhizospheric soil were carried out following the standard methodologies of the American Public Health Association. The results of the analysis are in favor of the steady increase in $\mathrm{Cr}(\mathrm{VI})$ accumulation in plant parts of the targeted plant with the increase in its concentration in rhizospheric soil. The novelty of this study focuses on the survival of P. pinnata (L.) Pierre on soil under high $\mathrm{Cr}$ (VI) stress conditions and the differential accumulation of $\mathrm{Cr}(\mathrm{VI})$ in its vital vegetative parts with the uptake of the toxic metal from the soil to reduce pollution. It is supported by the higher value coefficient of correlation during the uptake of $\mathrm{Cr}(\mathrm{VI})$ from polluted rhizospheric soil with its concentration in soils up to $200 \mu \mathrm{g} / \mathrm{g}$ soil. The order of accumulation of $\mathrm{Cr}(\mathrm{VI})$ in root $>$ leaf $>$ stem is significant at $p=0.05$ and $p=0.01$. Further work on this plant species, $P$. pinnata (L.) Pierre, can make it an elite species for remediation of $\mathrm{Cr}(\mathrm{VI})$-polluted soil.
\end{abstract}

\section{INTRODUCTION}

The release of hexavalent chromium $[\mathrm{Cr}(\mathrm{VI})]$ as a soil pollutant is increasing with the expansion of industrial production and metal processing units. $\mathrm{Cr}$ is an essential heavy metal having wide industrial uses. The tensile strength and anti-corrosion ability of chromium are beneficial parameters for it being used as an industrial component. The Cr-linked industrial and mining environment has witnessed the presence of $\mathrm{Cr}(\mathrm{VI})$ exceeding the threshold limits. Cr(VI) is highly toxic and expresses its toxicity in a wide range of living organisms [1]. The health of crop plants and

\footnotetext{
*Corresponding Author

Patitapaban Dash, Centre for Biotechnology, Siksha 'O'Anusandhan

(Deemed to be University), Bhubaneswar, India.

E-mail: patitapabandash@soa.ac.in
}

animal husbandry is not spared from its toxic effects. Moreover, similar to other heavy metals, the persistent nature of $\mathrm{Cr}(\mathrm{VI})$ raises the risk of being transferred through the food chain, thereby leading to bioaccumulation [2].

$\mathrm{Cr}(\mathrm{VI})$ pollution is intimately connected with the disruption of the biosphere. It is related to the rise in global population and rapid urbanization [3]. Anthropogenic activities like industrialization increase the incidence of soil pollution by $\mathrm{Cr}(\mathrm{VI}) . \mathrm{Cr}$ is the seventh-ranked element [4], and the sixth-ranked transition metal based on its abundance. It is available in several oxidation states ranging from 0 to +6 ; however, the +3 and +6 oxidation states are the two most stable forms [5] found in the soil environment.

$\mathrm{Cr}(\mathrm{VI})$ is highly toxic as compared to $\mathrm{Cr}$ (III) and imparts toxicity to public health when it exceeds the threshold limits. It has a very rare chance of occurring naturally; however, the formation of 
$\mathrm{Cr}(\mathrm{VI})$ from $\mathrm{Cr}$ (III) under oxidizing conditions is a possibility [6]. $\mathrm{Cr}(\mathrm{III})$ poses the chances of getting oxidized to $\mathrm{Cr}(\mathrm{VI})$ at a high $\mathrm{pH}$ of more than 5 [7]. The contamination of soil with $\mathrm{Cr}(\mathrm{VI})$ occurs mainly as a result of anthropogenic activities. The deposition of industrial waste is suspected to be a factor responsible for high $\mathrm{Cr}(\mathrm{VI})$ in the soil environment [8].

$\mathrm{Cr}(\mathrm{VI})$ is highly toxic and imparts more toxic effects on living organisms due to its high solubility in water [9]. It is responsible for occupational disorders and public health issues. In addition, human beings and other living organisms, like animals and plants, are not spared from its lethal effects. It expresses its lethal effects on exposed living organisms and the lethality on public health includes mutagenic, carcinogenic, and teratogenic effects. The cell cycle disturbances and genomic alterations are examples of severity of $\mathrm{Cr}(\mathrm{VI})$ toxicity [10].

Pongamia pinnata (L.) Pierre, selected for the present study, is a rapidly growing tree with spreading canopy cover and a commonly available plant in the humid and subtropical environment [11]. It grows in countries across the world like Australia, Bangladesh, China, Egypt, Fiji, India, Indonesia, Japan, Malaysia, Mauritius, Myanmar, Nepal, New Zealand, Pakistan, Philippines, Sri Lanka, Sudan, Thailand, and the United States of America [12] (Fig. 1). The presence of this plant species is also indicated at higher altitudes, even higher than 1,000 $\mathrm{m}$ above the sea level. These sites show a wider range of variations in rainfall and soil characteristics. Pollution of the environment due to $\mathrm{Cr}(\mathrm{VI})$ is a major concern and needs immediate attention. Biological remediation of $\mathrm{Cr}(\mathrm{VI})-$ contaminated soils using plant hyperaccumulators is preferable over other techniques for its eco-friendly approach. The current study aims to utilize $P$. pinnata (L.) Pierre as a tool for the remediation of $\mathrm{Cr}(\mathrm{VI})$-contaminated soils. The study examines the ability of the plant to accumulate toxic heavy metals like $\mathrm{Cr}(\mathrm{VI})$ in its parts like roots, stems, and leaves. Roots being the primary zone of contact of plants with the contaminated soil accumulates metals in its cells. This study works on the elucidation of the impact of $\mathrm{Cr}(\mathrm{VI})$ on the structural morphology of plant roots.

\section{MATERIALS AND METHODS}

\subsection{Selection of Target Plant Species}

The plant species targeted for this study was selected on the basis of its natural cosmopolitan distribution and high importance value index (IVI). The certified seeds collected for this experiment were germinated in pots filled with soil. The water content of the soil was maintained at three-quarter its water-holding capacity. The plants were watered regularly at an interval of 24 hour. The 45 -day-old seedlings were selected randomly for this experimental study.

\subsection{Experimental Setup}

The experiment was carried out in a randomized block design with the consideration of control plants and $\mathrm{Cr}(\mathrm{VI})$-contaminated soils of 10 different treatment concentrations. The plants in treatment conditions and control were studied in triplicates. Besides control, the soil treatment was carried out using equivalent amounts of potassium dichromate $\left(\mathrm{K}_{2} \mathrm{Cr}_{2} \mathrm{O}_{7}\right)$ as the chemical source of $\mathrm{Cr}(\mathrm{VI})$. In the 10 different soil $\mathrm{Cr}(\mathrm{VI})$ treatment conditions, the concentration of $\mathrm{Cr}(\mathrm{VI})$ was maintained between 50 and 500 $\mu \mathrm{g} / \mathrm{g}$ with a regular concentration interval of $50 \mu \mathrm{g} / \mathrm{g}$. Before plantation, each labelled pot was filled with $3 \mathrm{~kg}$ of $\mathrm{Cr}(\mathrm{VI})$ treated homogenized soil of desired concentrations. Pots marked as "C" were control and contained soil without $\mathrm{Cr}(\mathrm{VI})$. The pots containing $\mathrm{Cr}(\mathrm{VI})$-treated soil were labelled as $\mathrm{T} 1[50 \mu \mathrm{g} / \mathrm{g}$ Cr(VI)], T2 $(100 \mu \mathrm{g} / \mathrm{g}), \mathrm{T} 3(150 \mu \mathrm{g} / \mathrm{g}), \mathrm{T} 4(200 \mu \mathrm{g} / \mathrm{g})$ up to T10 $(500 \mu \mathrm{g} / \mathrm{g})$.



Figure 1: Cosmopolitan distribution of $P$. pinnata (L.) Pierre. 


\subsection{Assessment of $\mathrm{Cr}(\mathrm{VI})$ Accumulation in Plant Parts}

$\mathrm{Cr}(\mathrm{VI})$ accumulation in vital vegetative plant parts like roots, stems, and leaves was evaluated to determine the phytoremedial potential of the plant under varied soil $\mathrm{Cr}(\mathrm{VI})$ content. Each plant sample was first cut into pieces and cleaned properly with deionized water to remove any dust and debris. The plant samples were dried at $90^{\circ} \mathrm{C}$ for 24 hours and then ground into fine powder. The powdered plant samples were acid digested using $0.5 \mathrm{M} \mathrm{HNO}_{3}$ and the $\mathrm{Cr}(\mathrm{VI})$ estimation was carried out using atomic absorption spectroscopy, following the standard methodologies of the American Public Health Association [13]. Similarly, the analysis of $\mathrm{Cr}(\mathrm{VI})$ content in acidic solution was also conducted by a UVVis spectrophotometer as a confirmatory test to determine the $\mathrm{Cr}(\mathrm{VI})$ concentration in different plant parts. $\mathrm{Cr}(\mathrm{VI})$ was allowed to react with 1,5-diphenylcarbazide to give a characteristic colored complex which was analyzed at $540 \mathrm{~nm}$ to determine the $\mathrm{Cr}(\mathrm{VI})$ concentration in plant parts.

\subsection{Calculation of Biotic Index Values Using $P$. pinnata( L.) Pierre}

The biotic index values like bioconcentration factor (BCF), translocation factor (TF), and bioaccumulation coefficient (BAC) were calculated [14] using $P$. pinnata (L.) Pierre to estimate the $\mathrm{Cr}(\mathrm{VI})$ pollution of the soil as follows:

$\mathrm{BCF}=C_{\text {Plant }} / C_{\text {Soil }}$

where

$C_{\text {Plant }}=$ concentration of $\mathrm{Cr}(\mathrm{VI})$ in the plant and

$C_{\text {Soil }}=$ concentration of $\mathrm{Cr}(\mathrm{VI})$ in the soil $[15,16]$.

$\mathrm{TF}=C_{\text {Shoots }} / C_{\text {Roots }}$

where

$C_{\text {Shoots }}=$ concentration of $\mathrm{Cr}(\mathrm{VI})$ in the shoots or aerial parts of the plant and

$C_{\text {Roots }}=$ concentration of $\mathrm{Cr}(\mathrm{VI})$ in the roots [17].

$\mathrm{BAC}=C_{\text {Shoots }} / C_{\text {Soil }}$

where

$C_{\text {Shoots }}=$ concentration of $\mathrm{Cr}(\mathrm{VI})$ in the plant shoots, and

$C_{\text {Soil }}=$ concentration of $\mathrm{Cr}(\mathrm{VI})$ in the soil [18].

\subsection{Structural Study of Plant Roots Under Soil Cr(VI) Stress Condition}

Plants subjected to various concentrations of soil comprising $\mathrm{Cr}(\mathrm{VI})$ were studied for morphological changes occurring in the roots. The roots were observed for phenotypic changes, such as diameter and development of tap root system, when compared to that of the control.

\subsection{Physicochemical Analysis of Treated Soil}

The physicochemical analysis of the $\mathrm{Cr}(\mathrm{VI})$-treated soil was carried out following standard methodologies. The soil parameters tested were soil $\mathrm{pH}$, soil organic carbon content, and soil residual $\mathrm{Cr}(\mathrm{VI})$.

To measure the soil $\mathrm{pH}, 10 \mathrm{~g}$ of soil sample was taken in a 50 $\mathrm{ml}$ beaker and mixed thoroughly with $20 \mathrm{ml}$ of deionized water along with continuous stirring for 5 minutes. The suspension was allowed to stand for 1 hour, followed by filtration with Whatman filter paper. The aqueous filtrate was taken for measurement of $\mathrm{pH}[19]$.

The soil organic carbon content was analyzed following the methodology of Datta et al. [20]. $1 \mathrm{~g}$ of soil sample was taken and added with $10 \mathrm{ml}$ of $1 \mathrm{~N} \mathrm{~K}_{2} \mathrm{Cr}_{2} \mathrm{O}_{7}$ and $20 \mathrm{ml}$ of concentrated $\mathrm{H}_{2} \mathrm{SO}_{4}$ which contained $1.25 \%$ of $\mathrm{Ag}_{2} \mathrm{SO}_{4}$. The solution mixture was allowed to cool and then centrifuged. The absorbance of the chromous-colored supernatant formed was measured at $660 \mathrm{~nm}$ against a blank solution. The percentage of organic carbon was determined from a standard curve prepared using dilutions of glucose.

The residual $\mathrm{Cr}(\mathrm{VI})$ in the individual potted soil was measured at the end of the study by spectrophotometric analysis and was compared with the initial treatment provided.

\subsection{Statistical Analysis}

The data obtained were statistically validated using Statistical Package for the Social Sciences version 21.0 [21] software at probability levels of 0.05 and 0.01 .

\section{RESULTS AND DISCUSSION}

The ability of the plant $P$. pinnata (L.) Pierre to survive, grow, and hyperaccumulate $\mathrm{Cr}(\mathrm{VI})$ in its biomass from the $\mathrm{Cr}(\mathrm{VI})$ contaminated soil up to $200 \mu \mathrm{g} / \mathrm{g}$ soil is a noteworthy outcome of this study. The hyperaccumulation of $\mathrm{Cr}(\mathrm{VI})$ in its biomass can increase the residence time of the heavy metal in the living systems. It can reduce the possibility of $\mathrm{Cr}(\mathrm{VI})$ availability in free or binding states in the open environment.

The survival and growth of $P$. pinnata (L.) Pierre seedlings in soil treated with $\mathrm{Cr}(\mathrm{VI})$ concentrations $>200 \mu \mathrm{g} / \mathrm{g}$ soil and up to $500 \mu \mathrm{g} / \mathrm{g}$ soil, tried during this experiment, indicated a poor response. The trial with the survival and growth of seedlings on soil treated with $\mathrm{Cr}(\mathrm{VI})$ concentrations up to $200 \mu \mathrm{g} / \mathrm{g}$ soil and being maintained as control $(0 \mu \mathrm{g} / \mathrm{g}$ soil $)$ indicated an insignificant stress-induced response. It may be attributed to the ability of this plant species to resist toxicity, osmotic imbalance, reactive oxygen species, and ionic disturbances caused by the presence of $\mathrm{Cr}(\mathrm{VI})$ in the soil strata up to $200 \mu \mathrm{g} / \mathrm{g}$ soil. Hence, it paves the way for the study of the uptake and accumulation of $\mathrm{Cr}(\mathrm{VI})$ by $P$. pinnata (L.) Pierre from the soil treated with $\mathrm{Cr}(\mathrm{VI})$. The concentration of $\mathrm{Cr}(\mathrm{VI})$ varies from $0 \mu \mathrm{g} / \mathrm{g}$ soil (maintained as control) to $200 \mu \mathrm{g} / \mathrm{g}$ soil in the treated soil of this study.

\subsection{Uptake of $\mathrm{Cr}(\mathrm{VI})$ and Its Differential Accumulation in Plant Parts}

The success behind the use of a plant species as a hyperaccumulator up to a certain extent depends upon its root system development. $P$. pinnata (L.) Pierre with a well-developed tap root system having 
lateral roots is advantageous for being selected as an experimental species.

The analysis of variance (ANOVA) values relating to the interactions of $\mathrm{Cr}(\mathrm{VI})$ concentration used for soil treatment and mean post-treatment accumulation of $\mathrm{Cr}(\mathrm{VI})$ in soil and plant parts of $P$. pinnata (L.) Pierre are significant at $p=0.05$ and 0.01 levels (Table 1).

The ANOVA of the recorded data revealed that significant differences exist in the post-treatment accumulation of $\mathrm{Cr}(\mathrm{VI})$ in soil and plant parts of P. pinnata (L.) Pierre under the $\mathrm{Cr}(\mathrm{VI})$ soil treatment conditions. The values of accumulation of $\mathrm{Cr}(\mathrm{VI})$ in the roots of $P$. pinnata (L.) Pierre are recorded as $20.444 \pm 0.077$, $41.422 \pm 0.077,89.822 \pm 0.077$, and $116.311 \pm 0.077 \mu \mathrm{g} / \mathrm{g}$, with a significant increase in soil $\mathrm{Cr}(\mathrm{VI})$ treatment values of $50 \mu \mathrm{g} / \mathrm{g}$ soil (T1), $100 \mu \mathrm{g} / \mathrm{g}$ soil (T2), $150 \mu \mathrm{g} / \mathrm{g}$ soil (T3), and $200 \mu \mathrm{g} / \mathrm{g}$ soil (T4), respectively (Table 1). The short residence time of $\mathrm{Cr}(\mathrm{VI})$ on the soil surface makes this element highly mobile. Due to its mobility, it retains a higher probability to be absorbed by the root system of hyperaccumulators [22]. The higher concentration of $\mathrm{Cr}$ in the roots is due to its low mobility within the root tissues [23].

The values of accumulation of $\mathrm{Cr}(\mathrm{VI})$ in roots of $P$. pinnata (L.) Pierre is higher when compared to its accumulation in leaves under all the soil $\mathrm{Cr}(\mathrm{VI})$ treatment conditions up to $200 \mu \mathrm{g} / \mathrm{g}$ soil; an exception to this is the soil treatment with $50 \mu \mathrm{g} / \mathrm{g}$ soil $\mathrm{Cr}(\mathrm{VI})$. In this exceptional condition, $\mathrm{Cr}(\mathrm{VI})$ accumulation is more in leaves when compared to roots. This may be due to a high rate of movement of $\mathrm{Cr}(\mathrm{VI})$ from roots to leaves using the healthy translocation system of plants under low stress conditions of the soil. The values of accumulation of Cr(VI) in leaves of $P$. pinnata (L.) Pierre were found to be $24.178 \pm 0.077,35.522 \pm$ $0.077,60.967 \pm 0.077$, and $86.767 \pm 0.077 \mu \mathrm{g} / \mathrm{g}$. The accumulation of the toxic metal increased significantly with the increase in soil
$\mathrm{Cr}(\mathrm{VI})$ treatment values of $50 \mu \mathrm{g} / \mathrm{g}$ (T1), $100 \mu \mathrm{g} / \mathrm{g}$ (T2), $150 \mu \mathrm{g} / \mathrm{g}$ (T3), and $200 \mu \mathrm{g} / \mathrm{g}$ (T4), respectively (Table 1).

The values of accumulation of $\mathrm{Cr}(\mathrm{VI})$ in stems of $P$. pinnata (L.) Pierre is minimum when compared to its accumulation in roots and leaves under all the soil $\mathrm{Cr}$ (VI) treatment conditions up to 200 $\mu \mathrm{g} / \mathrm{g}$ soil. The values of accumulation of $\mathrm{Cr}(\mathrm{VI})$ in the stems of $P$. pinnata (L.) Pierre are analyzed to be $19.178 \pm 0.077,26.300 \pm$ $0.077,37.000 \pm 0.077$, and $45.367 \pm 0.077 \mu \mathrm{g} / \mathrm{g}$. A notable increase in the accumulation of heavy metal in the stem is observed with the increase in soil $\mathrm{Cr}(\mathrm{VI})$ treatment values of $50,100,150$, and $200 \mu \mathrm{g} / \mathrm{g}$, respectively (Table 1 ).

The values of residual $\mathrm{Cr}(\mathrm{VI})$ in the soil after accumulation by $P$. pinnata (L.) Pierre is $38.144 \pm 0.077,65.622 \pm 0.077,99.233 \pm$ 0.077 , and $148.878 \pm 0.077 \mu \mathrm{g} / \mathrm{g}$, which increased markedly with the increase in soil $\mathrm{Cr}(\mathrm{VI})$ treatment values of $50,100,150$, and $200 \mu \mathrm{g} / \mathrm{g}$, respectively (Table 1 ).

The plant $P$. pinnata (L.) Pierre demonstrated an increase in accumulation of $\mathrm{Cr}(\mathrm{VI})$ in its roots, leaves, and stems biomass with the increase in soil $\mathrm{Cr}(\mathrm{VI})$ toxicity. It is supported by the findings of Chitraprabha and Sathyavathi [24]. Maximum Cr(VI) accumulation is observed in the roots biomass, followed by its accumulation in the biomass of leaves and stems. The more accumulation of $\mathrm{Cr}(\mathrm{VI})$ in roots biomass may be attributed to the accumulation of heavy metal in the root cell vacuoles as a natural defensive mechanism $[25,26]$.

In the present study, increased accumulation of $\mathrm{Cr}(\mathrm{VI})$ in plants is observed along with the increment in soil $\mathrm{Cr}(\mathrm{VI})$ concentration. $\mathrm{Cr}(\mathrm{VI})$ is a toxic and non-essential substance for the plants and hence lacks any specific uptake mechanism. Plant uptake of Cr(VI) is an active mechanism that occurs mostly through anionic carriers like the sulfate and the phosphate carriers. A major part of $\mathrm{Cr}$ is mostly retained in the cortex of the plant root [27]. The xylem

Table 1: Effect of the variations in soil $\mathrm{Cr}(\mathrm{VI})$ treatment on its accumulation in parts of $P$. pinnata (L.) Pierre.

\begin{tabular}{|c|c|c|c|c|c|}
\hline \multirow{2}{*}{$\begin{array}{l}\text { Soil } \\
\text { treatment } \\
\text { code }\end{array}$} & \multirow{2}{*}{$\begin{array}{c}\mathrm{Cr}(\mathrm{VI}) \\
\text { concentration } \\
\text { used for soil } \\
\text { treatment (in } \mu \mathrm{g} / \mathrm{g} \\
\text { soil) }\end{array}$} & \multirow{2}{*}{$\begin{array}{l}\text { Mean post-treatment } \\
\text { accumulation of } \mathrm{Cr}(\mathrm{VI}) \text { in soil } \\
\text { (in } \mu \mathrm{g} / \mathrm{g} \text { soil) }\end{array}$} & \multicolumn{3}{|c|}{$\begin{array}{l}\text { Mean post-treatment accumulation of } \mathrm{Cr}(\mathrm{VI}) \text { in plant parts } \\
\text { (in } \mu \mathrm{g} / \mathrm{g} \text { soil) }\end{array}$} \\
\hline & & & Roots & Stems & Leaves \\
\hline T0 (Control) & 0 & 0.000 & 0.000 & 0.000 & 0.000 \\
\hline $\mathrm{T} 1$ & 50 & 38.144 & 20.444 & 19.178 & 24.178 \\
\hline $\mathrm{T} 2$ & 100 & 65.622 & 41.422 & 26.300 & 35.522 \\
\hline $\mathrm{T} 3$ & 150 & 99.233 & 89.822 & 37.000 & 60.967 \\
\hline $\mathrm{T} 4$ & 200 & 148.878 & 116.311 & 45.367 & 86.767 \\
\hline \multicolumn{3}{|c|}{$\mathrm{SE}(\mathrm{m})( \pm)$ for soil treatment } & 0.044 & & \\
\hline \multicolumn{3}{|c|}{$\mathrm{CD}(0.05)$ for soil treatment } & 0.124 & & \\
\hline \multicolumn{3}{|c|}{$\mathrm{SE}(\mathrm{m})( \pm)$ for post-treatment accumulation of $\mathrm{Cr}(\mathrm{VI})$} & 0.034 & & \\
\hline \multicolumn{3}{|c|}{$\mathrm{CD}(0.05)$ for post-treatment accumulation of $\mathrm{Cr}(\mathrm{VI})$} & 0.096 & & \\
\hline \multicolumn{3}{|c|}{$\begin{array}{l}\mathrm{SE}(\mathrm{m})( \pm) \text { for the interaction of treatment of soil and post-treatment } \\
\text { accumulation of } \mathrm{Cr}(\mathrm{VI})\end{array}$} & 0.077 & & \\
\hline \multicolumn{3}{|c|}{$\begin{array}{l}\mathrm{CD}(0.05) \text { for interactions of treatment and post-treatment accumulation } \\
\text { of } \mathrm{Cr}(\mathrm{VI})\end{array}$} & 0.215 & & \\
\hline
\end{tabular}

Significant at $p=0.05$ and 0.01 levels. 
tissues play a major role in this regard. The xylem tissues not only deposit $\mathrm{Cr}(\mathrm{VI})$ in the roots but also translocate the heavy metal through the conducting strands to the aerial parts. Xylem-assisted transfer of $\mathrm{Cr}(\mathrm{VI})$ is mostly associated with the involvement of membrane and transport proteins. This may be attributed to the structural similarity of $\mathrm{Cr}(\mathrm{VI})$ with that of phosphate or sulfate ions. Once inside the cells, the metals react with specific ligands, thus forming complexes. These complexes are then entrapped inside the cellular vacuoles rendering it less toxic.

\subsection{Correlation Studies}

The study of the correlation between the increase in soil $\mathrm{Cr}(\mathrm{VI})$ treatment and the accumulation of $\mathrm{Cr}(\mathrm{VI})$ in roots, stems, and leaves shows a significantly higher positive correlation with the coefficient of correlation $(r)$ of $0.986,0.983$, and 0.993, respectively (Fig. 2).

A comparatively high $r$-value between soil $\mathrm{Cr}(\mathrm{VI})$ treatment concentration and accumulation of $\mathrm{Cr}(\mathrm{VI})$ in leaves is an indication of efficient translocation of toxic $\mathrm{Cr}(\mathrm{VI})$ metal from roots to aerial parts of the plant species. It is supported by the observations made in the previous studies. Besides being efficient accumulators of metals, hyperaccumulator plants efficiently carry out metal translocation from the underground parts to the aerial parts of the plants [28]. This supports the use of the targeted plant, $P$. pinnata (L.) Pierre, as a suitable hyperaccumulator for phytoextraction of $\mathrm{Cr}(\mathrm{VI})$ from contaminated industrial and mining soils.

\subsection{Estimation of Biotic Index Values to Evaluate The Phytoremedial Ability of P. pinnata (L.) Pierre Under Cr(VI) Stress Conditions}

The plant parts were harvested after 180 days of treatment with $\mathrm{Cr}(\mathrm{VI}) . \mathrm{Cr}(\mathrm{VI})$ contents in the targeted plant parts were used to calculate the biotic indices such as BCF, TF, and BAC (Fig. 3). In plant $\mathrm{T} 1$, treated with $50 \mu \mathrm{g} \mathrm{Cr}(\mathrm{VI}) / \mathrm{g}$ soil, the $\mathrm{TF}$ value is highest, followed by $\mathrm{BCF}$ and $\mathrm{BAC}$. The other three treatment conditions, namely T2 [100 $\mu \mathrm{g} \mathrm{Cr}(\mathrm{VI}) / \mathrm{g}$ soil], T3 [150 $\mu \mathrm{g} \mathrm{Cr}(\mathrm{VI}) / \mathrm{g}$ soil], and T4 [200 $\mu \mathrm{g} \mathrm{Cr}(\mathrm{VI}) / \mathrm{g}$ soil], exhibited high BCF, followed by TF and $\mathrm{BAC}$ values. The reduction in the TF value of treated plants with a gradual increase in soil $\mathrm{Cr}(\mathrm{VI})$ toxicity indicates probable damage of the xylem tissues, thus impairing translocation of the heavy metal from roots to shoots. Under all the treatment conditions, plants exhibited BCF and TF values of more than 1 . A high BCF and TF value indicates the suitability of a plant as an hyperaccumulator $[29,30]$. Plants exhibiting a $\mathrm{BCF}>1$ and $\mathrm{TF}<$ 1 can be used for the phytostabilization of $\mathrm{Cr}$ in the soil [31]. In the current study, BCF and TF value $>1$ in all the conditions of treatment imply that the plant is not only able to accumulate high $\mathrm{Cr}(\mathrm{VI})$ in its root, but is also efficient in translocating the metal to its above ground parts. This strongly supports the suitability of this plant species as a potential hyperaccumulator for phytoremediation of $\mathrm{Cr}(\mathrm{VI})$-contaminated soils.

\subsection{Impact of Soil Cr(VI) Treatments on The Morphology of Accumulating Plant Roots}

The study of $\mathrm{Cr}(\mathrm{VI})$ impact on the root structure plays an important role as it is the channel for the movement of $\mathrm{Cr}(\mathrm{VI})$ from contaminated soil to the biomass of the targeted plants for phytoaccumulation. The impact is pronounced more on root morphology when compared to the structure of stems and leaves of $P$. pinnata (L.) Pierre. The roots of the plants are adversely affected by an elevation in the soil $\mathrm{Cr}(\mathrm{VI})$ concentration from $0 \mu \mathrm{g} \mathrm{Cr}(\mathrm{VI}) / \mathrm{g}$ soil (control) to $200 \mu \mathrm{g} \mathrm{Cr}(\mathrm{VI}) / \mathrm{g}$ soil at T4. The secondary and tertiary roots are affected with an increase in soil $\mathrm{Cr}(\mathrm{VI})$ concentration when compared to the control (C). The roots under increasing soil $\mathrm{Cr}(\mathrm{VI})$ toxicity [50 $\mu \mathrm{g} \mathrm{Cr}(\mathrm{VI}) / \mathrm{g}$ soil to $200 \mu \mathrm{g} \mathrm{Cr}(\mathrm{VI}) / \mathrm{g}$ soil] exhibited a gradual decrease in biomass and structure (Fig. 4). The diameter of primary roots of plants subjected to $50 \mu \mathrm{g} \mathrm{Cr}(\mathrm{VI}) / \mathrm{g}$ soil (T1) and $100 \mu \mathrm{g} \mathrm{Cr}(\mathrm{VI}) / \mathrm{g}$ soil (T2) is more when compared to the roots of the plant (T3) subjected to $150 \mu \mathrm{g} \mathrm{Cr}(\mathrm{VI}) / \mathrm{g}$ soil. The roots of the plant (T4) subjected to $200 \mu \mathrm{g} \mathrm{Cr}(\mathrm{VI}) / \mathrm{g}$ soil exhibited a sharp decline in its structure and the primary root had a lesser diameter when compared to the roots of the control and other plants under treatment.

This may be due to the damage caused to the root cell structure or inhibition of root cell division [32]. Cr has been found to adversely affect the root parameters like diameter, surface area, and root hair numbers as has been supported by the observations of Ali et al. [33]. The observations are supported by similar results from a recent study of $\mathrm{Cr}(\mathrm{VI})$ toxicity on roots of Lepidium sativum [34]. Impaired uptake of water and nutrients from the soil through the damaged root may cause metabolic and survival disturbances in plants $[35,36]$. $\mathrm{Cr}(\mathrm{VI})$-induced disruption of root cells may be due to the generation of reactive oxygen species $[37,38]$.

\subsection{Post-Treatment Analysis of Soil Physicochemical Parameters}

The phytoremediation of $\mathrm{Cr}(\mathrm{VI})$-contaminated soil using $P$. pinnata (L.) Pierre shows variation in soil parameters like $\mathrm{pH}$, organic carbon content, and residual $\mathrm{Cr}(\mathrm{VI})$ in all the four treatment conditions (T1, T2, T3, and T4) and control (C). The outcomes of this study were analyzed and post-analysis data are presented in Table 2. The $\mathrm{pH}$ is higher in the $\mathrm{Cr}(\mathrm{VI})$-treated soil when compared to the control. The $\mathrm{pH}$ of the soil shows a positive relationship with the increasing concentration of $\mathrm{Cr}(\mathrm{VI})$, except in case of T4 where it decreased. This may be due to the release of more organic acids to the rhizospheric soil at T4. It is supported by the increase in soil organic carbon percentage from $\mathrm{T} 1$ to T4. The organic carbon content is minimum in the control when compared to treatment conditions. It showed an increase in the soil organic carbon percentage with the increase in soil Cr(VI) content. Similar results were obtained by Zhang and Wang [39], suggesting that high amounts of heavy metals like $\mathrm{Cr}(\mathrm{VI})$ in the soil could drastically reduce the mineralization of organic carbon present in the soil, thus increasing its percentage. Enya et al. [40] studied the effect of several heavy metals on the soil organic carbon content. They found $\mathrm{Cr}$ to have weak inhibitory effects on the soil organic carbon content. The group found organic carbon content in the soil to be lower in the control when compared to the treatments. Another probable reason for the increase in soil organic carbon with an increase in soil $\mathrm{Cr}(\mathrm{VI})$ treatment may be the complex formation between the heavy metal and the organic matter [41]. 


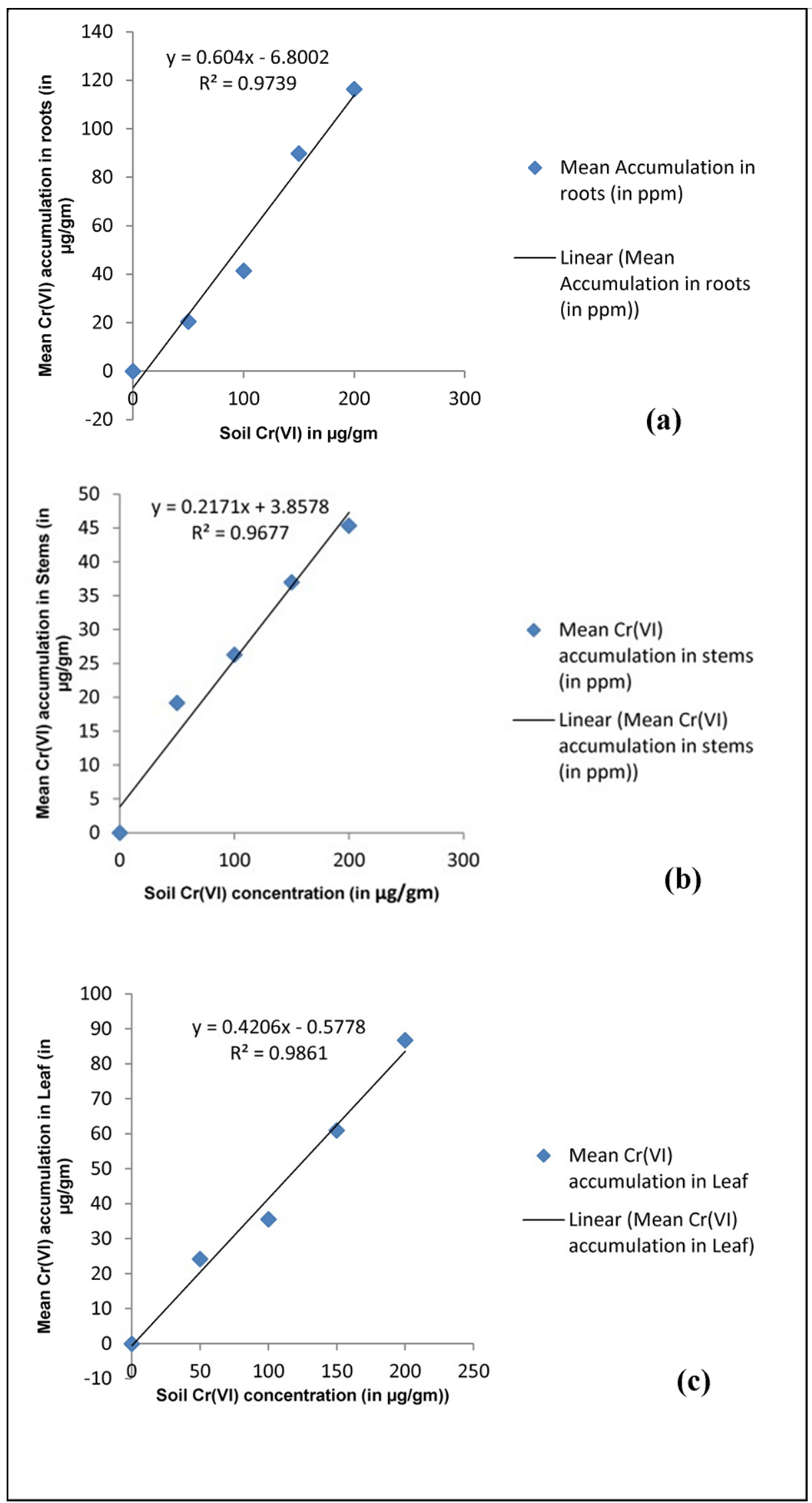

Figure 2: Correlation between soil $\mathrm{Cr}(\mathrm{VI})$ concentration and mean $\mathrm{Cr}(\mathrm{VI})$ accumulation in the (a) root, (b) stem, and (c) leaf biomass (Significant at $p=0.05$ and 0.01 levels). 




Figure 3: Biotic index values of $P$. pinnata (L.) Pierre under Cr(VI) soil stress conditions [T1: plant with soil $\mathrm{Cr}(\mathrm{VI})$ treatment of $50 \mu \mathrm{g} \mathrm{g}^{-1}$, T2: plant with soil $\mathrm{Cr}(\mathrm{VI})$ treatment of $100 \mu \mathrm{g} \mathrm{g}^{-1}$, T3: plant with soil $\mathrm{Cr}(\mathrm{VI})$ treatment of $150 \mu \mathrm{g} \mathrm{g}^{-1}$, and T4: plant with soil $\mathrm{Cr}(\mathrm{VI})$ treatment of $200 \mu \mathrm{g} \mathrm{g}^{-1}$ ].

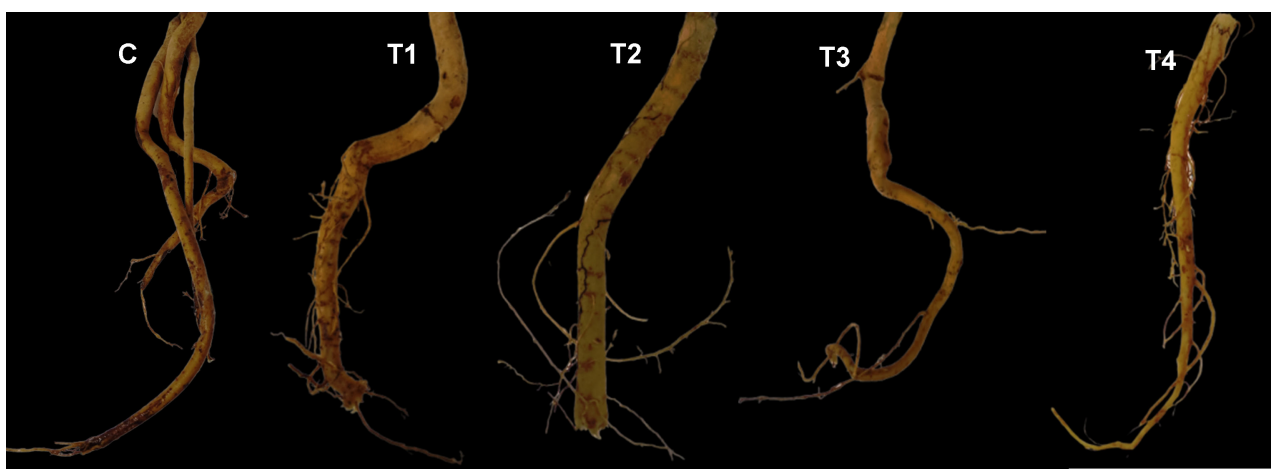

Figure 4: Effect of $\mathrm{Cr}(\mathrm{VI})$ toxicity on the structure of roots of P. pinnata (L.) Pierre [C: control plant, T1: plant with soil $\mathrm{Cr}(\mathrm{VI})$ treatment of $50 \mu \mathrm{g} \mathrm{g}^{-1}, \mathrm{~T} 2$ : plant with soil $\mathrm{Cr}(\mathrm{VI})$ treatment of $100 \mu \mathrm{g} \mathrm{g}^{-1}$, T3: plant with soil $\mathrm{Cr}(\mathrm{VI})$ treatment of $150 \mu \mathrm{g} \mathrm{g}^{-1}$, and T4: plant with soil $\mathrm{Cr}(\mathrm{VI})$ treatment of $200 \mu \mathrm{g} \mathrm{g}^{-1}$.

Table 2: Analysis of post-treatment soil physicochemical parameters (after 180 days of treatment).

\begin{tabular}{lccc} 
Initial soil Cr(VI) status & $\mathbf{p H} \pm \mathbf{S D}$ & $\mathbf{\%}$ organic carbon $\pm \mathbf{S D}$ & $\operatorname{Residual~Cr(VI)} \pm \mathbf{S D}$ \\
$\mathrm{C}(0 \mu \mathrm{g} / \mathrm{g}$ soil $)$ & $5.52 \pm 0.01$ & $0.38 \pm 0.0$ & - \\
$\mathrm{T} 1(50 \mu \mathrm{g} / \mathrm{g}$ soil $)$ & $5.84 \pm 0.0$ & $0.70 \pm 0.0$ & $38.144 \pm 0.077$ \\
$\mathrm{~T} 2(100 \mu \mathrm{g} / \mathrm{g}$ soil $)$ & $6.36 \pm 0.01$ & $0.83 \pm 0.0$ & $65.622 \pm 0.077$ \\
$\mathrm{~T} 3(150 \mu \mathrm{g} / \mathrm{g}$ soil $)$ & $7.21 \pm 0.01$ & $1.32 \pm 0.01$ & $99.233 \pm 0.077$ \\
$\mathrm{~T} 4(200 \mu \mathrm{g} / \mathrm{g}$ soil $)$ & $5.86 \pm 0.01$ & $1.47 \pm 0.0$ & $148.878 \pm 0.077$ \\
\hline
\end{tabular}

\section{CONCLUSION}

The results of this study are in favor of treating the plant $P$. pinnata (L.) Pierre as a suitable species for the remediation of soil under $\mathrm{Cr}(\mathrm{VI})$ stress up to $200 \mu \mathrm{g} / \mathrm{g}$. The accumulation of $\mathrm{Cr}(\mathrm{VI})$ is more in roots of this plant species when compared to the stems and leaves, during its growth in soil contaminated with $\mathrm{Cr}(\mathrm{VI})$ ranging between $100 \mu \mathrm{g} / \mathrm{g}$ and $200 \mu \mathrm{g} / \mathrm{g}$. The differential accumulation of $\mathrm{Cr}(\mathrm{VI})$ in plant parts of $P$. pinnata (L.) Pierre is highly significant at $p=0.05$ and $p=0.01$ levels. The mean $\mathrm{Cr}(\mathrm{VI})$ bioaccumulation in roots, stems, and leaves shows a high positive correlation with the soil $\mathrm{Cr}(\mathrm{VI})$ concentration. The targeted plant species, $P$. pinnata (L.) Pierre, is a possible tool for the phytoremediation of $\mathrm{Cr}(\mathrm{VI})$-contaminated soils of industrial and mining areas. 


\section{ACKNOWLEDGEMENT}

The authors acknowledge the support provided by Siksha 'O' Anusandhan (Deemed to be University) during the course of this research.

\section{AUTHOR CONTRIBUTIONS}

All authors made substantial contributions to conception and design, acquisition of data, or analysis and interpretation of data; took part in drafting the article or revising it critically for important intellectual content; agreed to submit to the current journal; gave final approval of the version to be published; and agree to be accountable for all aspects of the work. All the authors are eligible to be an author as per the international committee of medical journal editors (ICMJE) requirements/guidelines.

\section{CONFLICTS OF INTEREST}

The authors report no financial or any other conflicts of interest in this work.

\section{ETHICAL APPROVALS}

This study does not involve experiments on animals or human subjects.

\section{REFERENCES}

1. Peng H, Guo J. Removal of chromium from wastewater by membrane filtration, chemical precipitation, ion exchange, adsorption electrocoagulation, electrochemical reduction, electrodialysis, electrodeionization, photocatalysis and nanotechnology: a review. Environ Chem Lett 2020;18:2055-68; doi:10.1007/s10311-020-01058-x

2. Malik LA, Bashir A, Qureashi A, Pandit AH. Detection and removal of heavy metal ions: a review. Environ Chem Lett 2019;17:1495-521; doi:10.1007/s1031 1-019-00891 -Z

3. Emamverdian A, Ding Y, Mokhberdoran F, Xie Y. Heavy metal stress and some mechanisms of plant defense response. Sci World J 2015;18; doi:10.1155/2015/756120

4. Pradas del Real AE, perez-Sanz A, Lobo MC, McNear Jr. DH. The chromium detoxification pathway in the multimetal accumulator Silene vulgaris. Environ SciTechnol 2014;48:11479-86; doi:10.1021/ es502099g.

5. Das PK, Das BP, Dash P. Role of plant species as hyper-accumulators in the decontamination of hexavalent chromium contaminated soil. Indian J Environ Prot 2018;38(12):1016-24.

6. Das PK, Das BP, Dash P. Chromite mining pollution, environmental impact, toxicity and phytoremediation: a review. Environ Chem Lett 2021;19(2):1369-81; doi:10.1007/s10311-020-01102-w

7. Seaman JC, Arey JS, Bertsch PM. Immobilization of nickel and other metals in contaminated sediments by hydroxyapatite addition. J Environ Qual 2001;30:460-9.

8. Economou-Eliopoulos M, Megremi I, Vasilatos C. Factors controlling the heterogeneous distribution of $\mathrm{Cr}(\mathrm{VI})$ in soil, plants and groundwater: evidence from the assopos basin, Greece. Geochem 2011;71(1):39-52.

9. Das BK, Das PK, Das BP, Dash P. Green technology to limit the effects of hexavalent chromium contaminated water bodies on public health and vegetation at industrial sites. J Appl Biol Biotechnol 2021;9(2):28-35; doi:10.7324/JABB.2021.9203

10. Das PK, Das BP, Dash P. Hexavalent chromium induced toxicity and its remediation using macrophytes. Pollut Res 2017;36(1):92-8.

11. Allen ON, Allen EK. The Leguminosae. The University of Wisconsin Press, Madison, WI, 812 p, 1981.

12. Orwa C, Mutua A, Kindt R, Jamnagass R, Anthony S. Agroforest tree database. World Agroforestry Centre, Nairobi, Kenya, 491 p, 2009.
13. Americal Public Health Association. Standard Methods for the Examination of Water and Wastewater. 18th edition, Americal Public Health Association, Washington, DC, 1998.

14. Sajad MA, Khan MS, Bahadur S, Naeem A, Ali H, Batool F, et al. Evaluation of chromium phytoremediation potential of some plant species of Dir Lower, Khyber Pakhtunkhwa, Pakistan. Acta Ecol Sin 2020;40(2):158-65

15. Usman K, Al-Ghouti MA, Abu-Dieyeh MH. The assessment of cadmium, chromium, copper, and nickel tolerance and bioaccumulation by shrub plant Tetraenaqataranse. Sci Rep 2019;9(1):1-1.

16. Torralba-Sanchez TL, Kuo DT, Allen HE, Di Toro DM. Bioconcentration factors and plant-water partition coefficients of munitions compounds in barley. Chemosphere 2017;189:538-46.

17. Adesodun JK, AtayeseMO,Agbaje TA, Osadiaye BA, Mafe OF, Soretire AA. Phytoremediation potentials of sunflowers (Tithoniadiversifolia and Helianthus annus) for metals in soils contaminated with zinc and lead nitrates. Water Air Soil Pollut 2010;207(1):195-201.

18. Malik RN, Husain SZ, Nazir I. Heavy metal contamination and accumulation in soil and wild plant species from industrial area of Islamabad, Pakistan. Pak J Bot 2010;42(1):291-301.

19. USEPA.Soil and waste $\mathrm{pH}$. Method 9045D. USEPA, Washington, DC, 2004.

20. Datta NP, Khera MS, Saini TR. A rapid colorimetric procedure for the determination of organic carbon in soils. J Indian Soc Soil Sci 1962;10(1):67-74.

21. IBM SPSS Statistics for Windows, Version 21.0. IBM Corp, Armonk, NY,2013.

22. Lattanzi P, Aquilanti G, Rosellini I, Iadecola A, Bardelli F, et al. Spectroscopic evidence of $\mathrm{Cr}(\mathrm{VI})$ reduction in a contaminated soil by in situ treatment with whey. Agrochim Int J Plant Chem Soil Sci Plant Nutr Univ Pisa 2015;59(3):218-30.

23. Gupta AK, Sinha S. Chemical fractionation and heavy metal accumulation in the plant of Sesamumindicum(L.) var. T55 grown on soil amended with tannery sludge: selection of singleextractants. Chemosphere 2006;64:161-73.

24. Chitraprabha K, Sathyavathi S. Phytoextraction of chromium from electroplating effluent by Taegeteserecta. Sustain Environ Res 2018;28(3):128-34; doi:10.1016/j.serj.2018.01.002.

25. Mangabeira PA, Ferreira AS, de Almeida AAF, Fernandes VF, Lucena E, Souza VL, et al. Compartmentalization and ultrastructuralalterations induced by chromium in aquatic macrophytes. Biometals 2011;24:1017-26.

26. Kabata-Pendias A, Szteke B. Trace elements in abiotic and biotic environments. CRC Press, Boca Raton, FL, 2015.

27. Shanker AK, Djanaguiraman M, Sudhagar R, Chandrashekar $\mathrm{CN}$, Pathmanabhan G. Differential antioxidative response of ascorbate glutathione pathway enzymes and metabolites to chromium speciation stress in green gram (Vignaradiata (L.) R. Wilczek. cv CO 4) roots. Plant Sci 2004;166(4):1035-43.

28. Das PK. Phytoremediation and nanoremediation : emerging techniques for treatment of acid mine drainage water. Def Life Sci J 2018;3(2):190-6; doi:10.14429/dlsj.3.11346

29. Were FH, Wafula GA, Wairungu S. Phytoremediation using bamboo to reduce the risk of chromium exposure from a contaminated tannery site in Kenya. J Health Pollut 2017;7(16):12-25.

30. Xiao F, Gu Z, Sarkissian A, Ji Y, Yang L, Zeng Q, et al. Phytoremediation of potentially toxic elements in a polluted industria soil using Poinsettia. Physiol Mol Biol Plants 2021;27(4):675-86.

31. Srivastava D, Tiwari M, Dutta P, Singh P, Chawda K, Kumari M, et al. Chromium stress in plants: toxicity, tolerance and phytoremediation. Sustainability 2021;13(9):4629.

32. Wakeel A, Ali I, Upreti S, Azizullah A, Liu B, Khan AR, et al. Ethylene mediates dichromate-induced inhibition of primary root growth by altering AUX1 expression and auxin accumulation in Arabidopsis thaliana. Plant Cell Environ 2018;41:1453-67. 
33. Ali S, Zeng F, Qiu L, Zhang G. The effect of chromium and aluminum on growth, root morphology, photosynthetic parameters and transpiration of the two barley cultivars. Biol Plant 2011;55:291-6.

34. Diaconu M, Pavel LV, Hlihor RM, Rosca M, Fertu D, Lenz M, et al. Characterization of heavy metal toxicity in some plants and microorganisms - A preliminary approach for environmental bioremediation. New Biotechnol 2020;56:130-9; doi:10.1016/j. nbt.2020.01.003

35. Farooq M, Ali S, Hameed A, Bharwana S, Rizwan M, Ishaque W, et al. Cadmium stress in cotton seedlings: physiological, photosynthesis and oxidative damages alleviated byglycinebetaine. S Afr J Bot 2016;104:61-8.

36. Reale L, Ferranti F, Mantilacci S, Corboli M, Aversa S, Landucci $\mathrm{F}$, et al. Cyto-histological and morpho-physiological responses of common duckweed (Lemna minor L.) to chromium. Chemosphere 2016;145:98-105.

37. Anjum SA, Ashraf U, Khan I, Tanveer M, Shahid M, Shakoor A, et al.Phyto-toxicity of chromium in maize: oxidative damage, osmolyte accumulation, anti-oxidative defenseand chromium uptake. Pedosphere 2017;27:262-73.

38. Sharma A, Kapoor D, Wang J, Shahzad B, Kumar V, Bali AS, et al. Chromium bioaccumulation and its impacts on plants: an overview. Plants 2020;9:100; doi:10.3390/plants9010100
39. Zhang MK, Wang LP. Impact of heavy metals pollution on soil organic matter accumulation. Ying Yong Sheng Tai Xue Bao J Appl Ecol 2007;18(7):1479-83.

40. Enya O, Heaney N, Iniama G, Lin C. Effects of heavy metals on organic matter decomposition in inundated soils: microcosm experiment and field examination. Sci Total Environ 2020;724:138223.

41. Li G, Lu N, Wei Y, Zhu D. Relationship between heavy metal content in polluted soil and soil organic matter and $\mathrm{pH}$ in mining areas. IOP Conference Series: Materials Science and Engineering. IOP Publishing, Bristol, UK, vol. 394(5), 2018.

\section{How to cite this article:}

Das PK, Das BP, Dash P. Analytical study on hexavalent chromium accumulation in plant parts of Pongamia pinnata (L.) Pierre and remediation of contaminated soil. J Appl Biol Biotech 2022; 10(01):22-30. 